\title{
RANCANG BANGUN PENGUKUR LAJU DETAK JANTUNG BERBASIS PLC MIKRO
}

\author{
Dena Anugrah $^{1}$, Arjuni Budi Pantjawati ${ }^{2}$, Yoyo Somantri ${ }^{3}$ \\ Pendidikan Teknik Elektro \\ Email: denaanugrah@yahoo.co.id
}

\begin{abstract}
ABSTRAK
Artikel ini bertujuan untuk melakukan rancang bangun pengukur laju detak jantung yang terdiri dari perangkat keras dan perangkat lunak. Kalibrasi dilakukan dengan menggunakan alat medis Automatic Blood Pressure Monitor. Alat yang dirancang dibuat menggunakan PLC mikro yang diprogram dengan perangkat lunak LDmicro. Teknologi optik LED inframerah dan fotodioda digunakan untuk mendeteksi aliran darah di dalam kulit jari. Dari hasil pengukuran didapat bahwa alat ini memiliki tingkat kesalahan 0,198\%. Nilai ini masih di bawah nilai kesalahan yang masih bisa ditolelir yakni sebesar 0,6745\%. Jadi dapat disimpulkan bahwa alat yang dirancang dapat digunakan untuk mengukur laju detak jantung dengan akurasi yang sesuai dengan standar pengukuran yang berlaku.
\end{abstract}

Kata kunci: Laju detak jantung, PLC mikro, LDmicro

\section{PENDAHULUAN}

Laju detak jantung merupakan salah satu parameter yang sangat penting dalam sistem kardiovaskular manusia. Setiap orang memiliki laju detak jantung yang berbeda-beda tergantung pada kebugaran, usia dan genetika. Ketika laju detak jantung tidak beraturan, hal tersebut bisa menjadi tanda kritis. Banyaknya penderita penyakit jantung pada saat ini menjadi suatu alasan mengapa kita harus selalu mengukur keadaan laju detak jantung.

Pengukuran laju detak jantung digunakan oleh para ahli medis untuk membantu dalam mendiagnosis kondisi pasien. Terdapat beberapa metode yang dapat dilakukan untuk mengukur laju detak jantung, seperti Electrocardiogram (ECG), Phonocardiogram (PCG) maupun Auskultasi. Namun metode tersebut bersifat klinis, mahal dan hanya dapat dilakukan oleh orang-orang yang ahli di bidangnya. Oleh karena itu, dibutuhkan adanya suatu alat pengukur laju detak jantung yang dapat digunakan secara mudah, aman, dan spesifik.

Laju detak jantung diukur dalam satuan waktu yang dinyatakan dalam beats per minute (bpm). Laju detak jantung orang dewasa yang normal berkisar antara 60 sampai $100 \mathrm{bpm}$. Kelainan detak jantung dapat terjadi ketika lajunya kurang dari 60 bpm yang dikenal sebagai bradikardia. Selain itu, kelainan detak jantung juga dapat terjadi ketika lajunya melebihi 100 bpm yang dikenal sebagai takikardia.

Dari beberapa jurnal yang membahas tentang rancang bangun alat pengukur laju detak jantung, belum ada perancangan alat dengan hasil pengukuran yang akurat tanpa adanya kesalahan (error) dalam pengukurannya. Nilai rata-rata tingkat kesalahan (error rate) perancangan alat pengukur laju detak jantung dari beberapa jurnal tersebut berkisar antara $1,414 \%$ sampai $4,104 \%$.

\section{METODE}

Metode yang digunakan dalam pembuatan alat pengukur laju detak jantung ini yaitu merancang perangkat keras (hardware) dan perangkat lunak (software) kemudian mengkalibrasinya dengan alat medis yang dapat mengukur laju detak jantung. 


\section{Perancangan Perangkat Keras}

\section{Perancangan PLC Mikro}

Perancangan PLC mikro ini dibagi menjadi empat bagian yang terdiri dari catu daya, ICSP, mikrokontroler, dan komunikasi seperti yang nampak pada Gambar 1. Catu daya dalam rangkaian ini berfungsi sebagai input tegangan dari AC adaptor. ICSP (In Circuit Serial Programming) dalam rangkaian ini berfungsi sebagai jalur untuk menanamkan bootloader pada PLC mikro. Mikrokontroler dalam rangkaian ini berfungsi sebagai pusat kontrol, dimana ketiga bagian yang lainnya terhubung secara langsung dengan bagian mikrokontroler. Komunikasi dalam rangkaian ini berfungsi untuk melakukan pertukaran data secara serial dengan komputer.

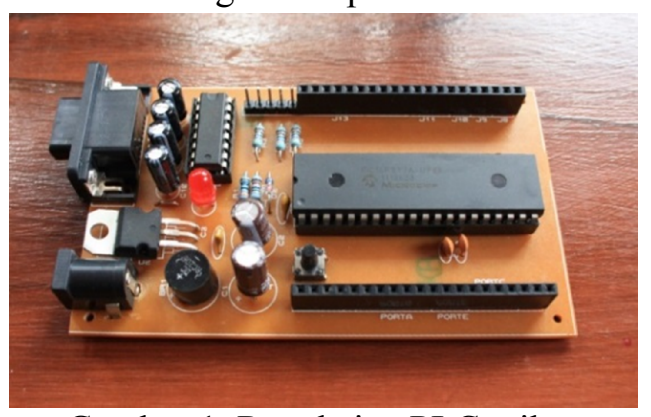

Gambar 1. Rangkaian PLC mikro PIC16F877A

\section{Perancangan Pengukur Laju Detak Jantung}

Perancangan pengukur laju detak jantung ini dibagi menjadi tiga bagian rangkaian yang terdiri dari rangkaian sensor, rangkaian filter, dan rangkaian penguat seperti yang nampak pada Gambar 2. Rangkaian sensor terdiri dari komponen LED inframerah sebagai transmitter dan komponen fotodioda sebagai receiver. Rangkaian sensor ini berfungsi untuk mendeteksi aliran darah di dalam kulit pada arteri radial ujung jari yang merepresentasikan detak jantung. Rangkaian filter menggunakan jenis Band Pass Filter (BPF) yang terdiri dari High Pass Filter (HPF) pasif dan Low Pass Filter (LPF) aktif dengan frekuensi cutoff antara 1,54 Hz sampai 2,34 Hz. Rangkaian filter ini berfungsi untuk menghilangkan distorsi dan melewatkan frekuensi tertentu yang dibutuhkan. Sedangkan pada rangkaian penguat menggunakan jenis operational amplifier non inverting yang terdapat pada komponen IC LM358. Rangkaian penguat ini berfungsi untuk menguatkan tegangan yang sebelumnya telah terdeteksi oleh rangkaian sensor.

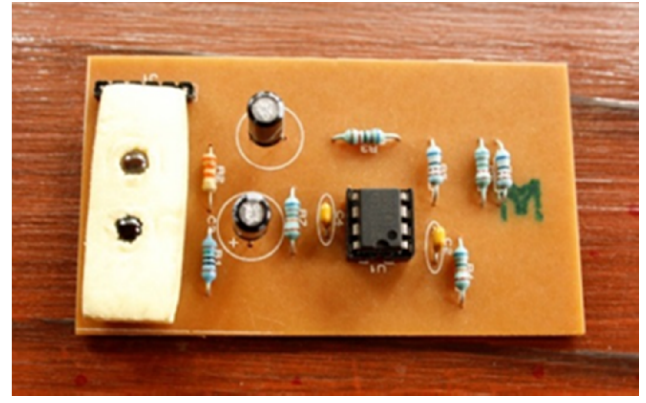

Gambar 2. Rangkaian pengukur laju detak jantung

\section{SPC Low Cost Serial LCD}

SPC (Smart Peripheral Controller) Low Cost Serial LCD merupakan sebuah modul pengendali karakter yang mendukung jalur antarmuka UART sehingga dapat lebih menghemat dan mempermudah pengkabelan. Pada perancangan alat pengukur laju detak jantung digunakan jenis LCD Serial dengan modul 16 x 2 dengan backlight seperti yang nampak pada Gambar 3. Alamat DDRAM pada LCD jenis ini yaitu $00 \mathrm{H}$ sampai dengan 0FH untuk baris pertama dan $40 \mathrm{H}$ sampai dengan 4FH untuk baris kedua. Sumber tegangan catu daya modul yang digunakan pada perancangan alat ini yaitu 12 volt dengan regulator tegangan sebesar 5 volt. Konektor UART TTL digunakan pada jalur RX sebagai jalur data masuk ke modul yang nantinya akan ditampilkan pada LCD Serial melalui konektor LCD

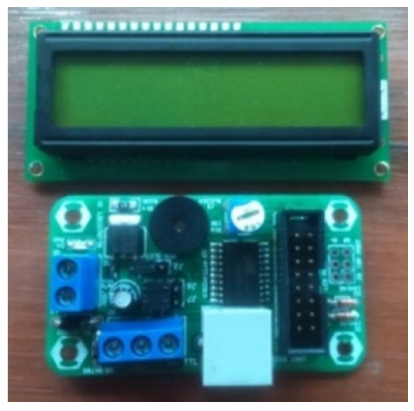

Gambar 3. SPC Low Cost Serial LCD 


\section{Perancangan Perangkat Lunak}

\section{LDmicro}

LDmicro merupakan sebuah software pemrograman berbentuk gambar diagram tangga yang menghasilkan kode mesin dengan file hex dan dapat digunakan untuk memprogram mikrokontroler keluarga PIC. Software ini dapat memeriksa programnya terlebih dahulu sebelum hasilnya di upload ke mikrokontroler. Software ini dapat menggabungkan editor, assembler, compiler, dan debugger dalam satu lingkungan [3]. Gambar 4 menunjukan bahasa pemrograman yang digunakan dalam perancangan alat pengukur laju detak jantung.

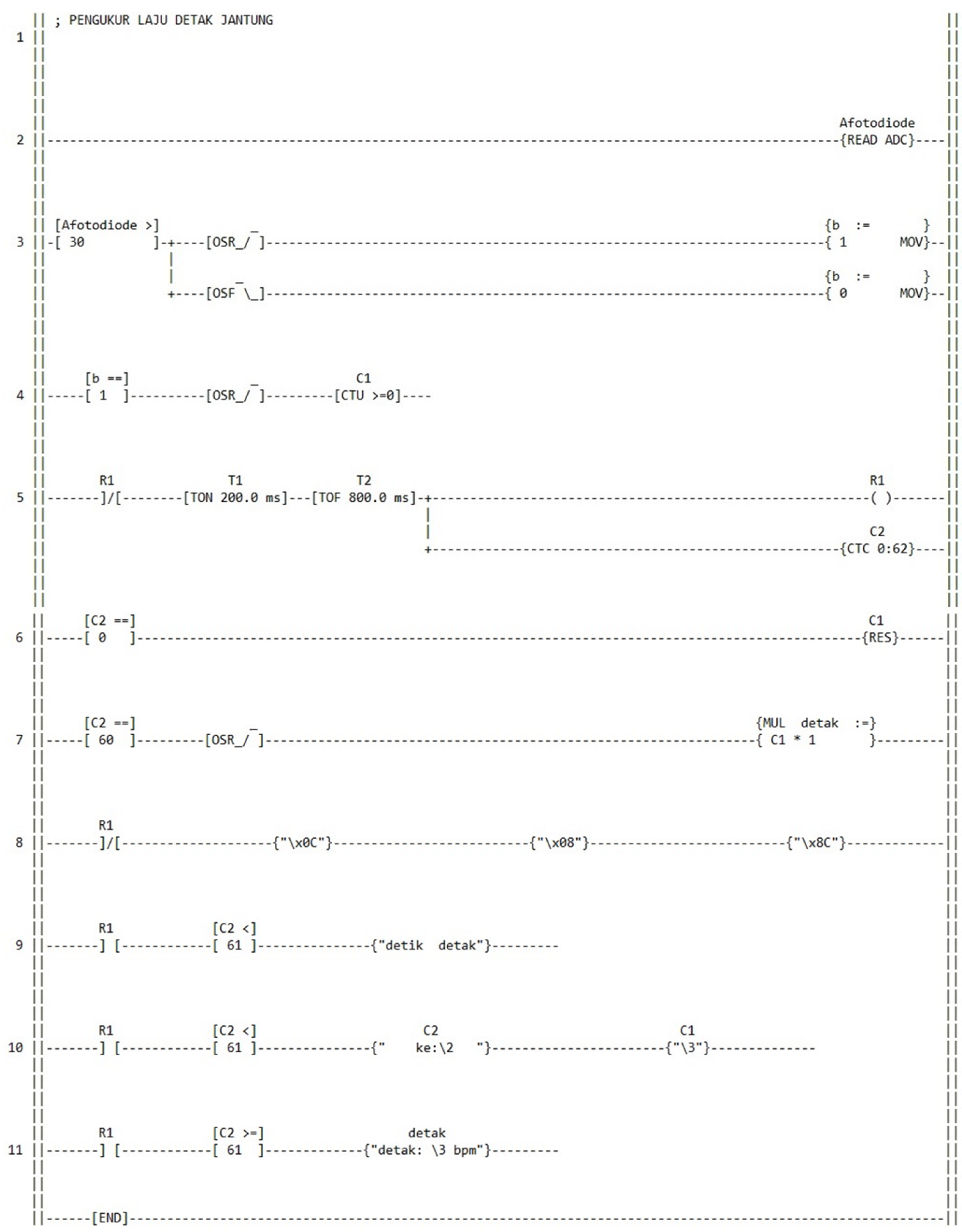

Gambar 4. Bahasa pemrograman pengukur laju detak jantung menggunakan software LDmicro 
Di bawah ini merupakan penjelasan bahasa pemrograman yang digunakan pada perancangan alat pengukur laju detak jantung:

- Anak tangga ke 1 digunakan untuk memberikan keterangan mengenai isi program pengukur laju detak jantung.

- Anak tangga ke 2 digunakan untuk membaca sinyal analog dari fotodioda menjadi data digital.

- Anak tangga ke 3 digunakan untuk mengubah sinyal analog fotodioda menjadi data digital dengan cara membandingkan nilai sinyal analog tersebut terhadap nilai ambang batas tertentu.

- Anak tangga ke 4 digunakan untuk menghitung jumlah data digital yang masuk dengan hitungan naik ke dalam variabel $\mathrm{C} 1$ yang nilainya lebih besar atau sama dengan 0 .

- Anak tangga ke 5 digunakan untuk membangkitkan pulsa dengan periode $1000 \mathrm{~ms}$ dengan menunda kondisi 1 hingga waktu delay $200 \mathrm{~ms}$ dan menunda kondisi 0 hingga waktu delay $800 \mathrm{~ms}$, serta me-reset variabel C2 ketika sudah mencapai 62 detik.

- Anak tangga ke 6 digunakan sebagai instruksi ketika variabel C2 sama dengan 0 detik, maka variabel $\mathrm{C} 1$ akan di reset.

- Anak tangga ke 7 digunakan untuk mengkalikan variabel $\mathrm{C} 1$ dengan 1 yang hasil perhitungannya akan dimasukan ke dalam variabel detak sebagai hasil perhitungan laju detak jantung.

- Anak tangga ke 8 digunakan untuk mengontrol tampilan LCD seperti menghapus atau membersihkan tampilan layar LCD dan mengatur fungsi LCD.

- Anak tangga ke 9 digunakan untuk menampilkan tulisan "detik detak" sebagai judul pembacaan.

- Anak tangga ke 10 digunakan untuk menampilkan tulisan "ke:" dengan tampilan 2 digit angka untuk variabel C2 yang menunjukan detik dan tampilan 3 digit angka untuk variabel $\mathrm{C} 1$ yang menunjukan detak.

- Anak tangga ke 11 digunakan untuk menampilkan tulisan "detak" dengan tampilan 3 digit angka disertai satuannya "bpm" sebagai hasil pengukuran laju detak jantung.

Dari bahasa pemrograman diatas, maka flowchart program pengukur laju detak jantung dapat dilihat pada Gambar 5 


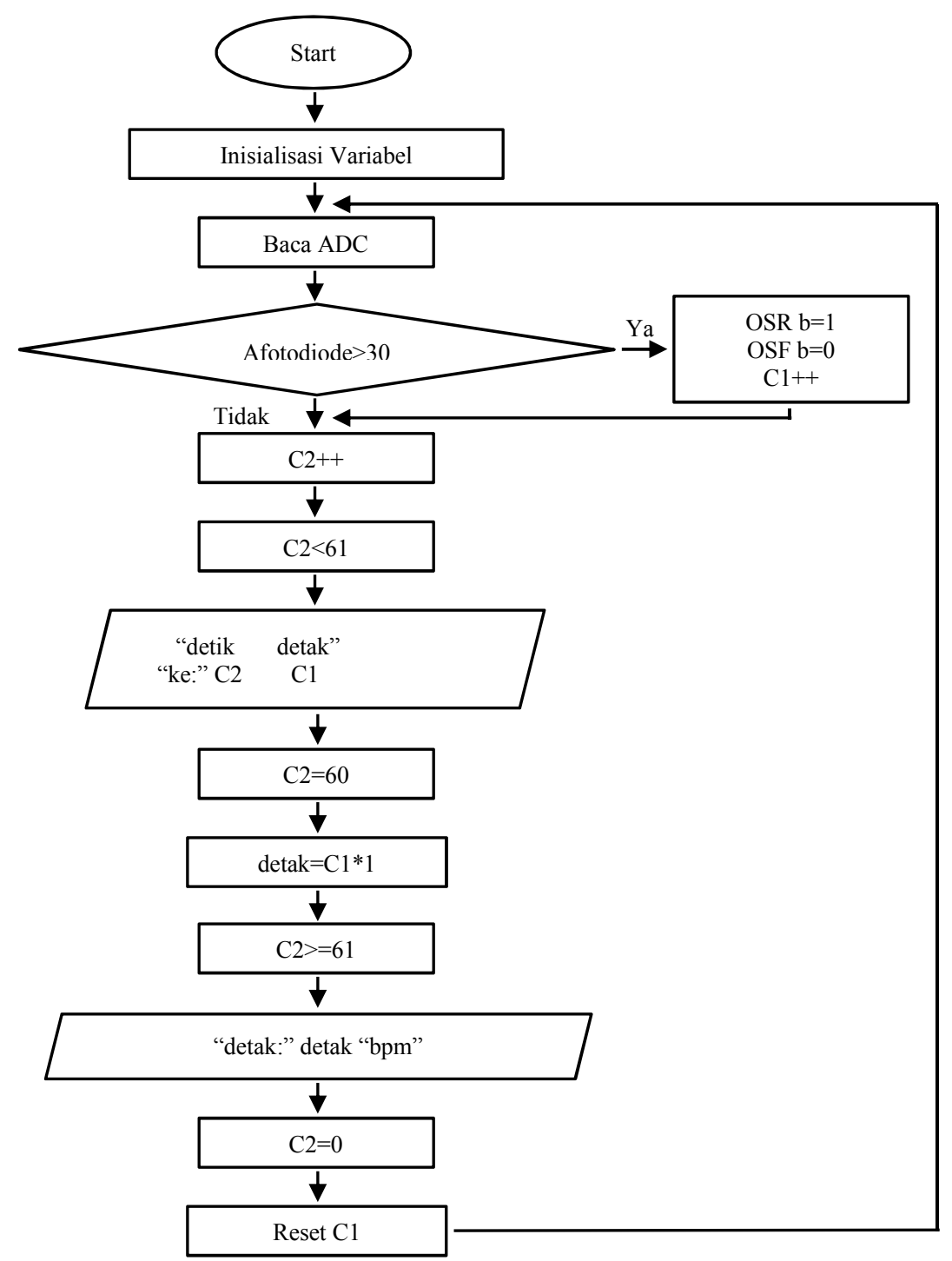

Gambar 5. Flowchart program pengukur laju detak jantung

Flowchart program pengukur laju detak jantung dimulai dengan menginisialisasi variabel program. Setelah variabel program diinisialilasi maka proses selanjutnya yaitu membaca ADC. Ketika variabel Afotodiode lebih besar dari 30 sebagai nilai ambang batas, maka instruksi OSR akan menghasilkan nilai 1 dan instruksi OSF akan menghasilkan nilai 0 yang kemudian hasil nilainya akan dimasukan ke dalam variabel $b$. Pada saat variabel $b$ bernilai 1 maka variabel $\mathrm{C} 1$ yang menunjukan detak jantung nilainya akan bertambah, namun pada saat variabel $b$ bernilai 0 maka variabel $\mathrm{C} 1$ nilainya tetap. Pada saat variabel $\mathrm{b}$ bernilai 1 ataupun 0 maka variabel $\mathrm{C} 2$ yang menunjukan detik nilainya akan bertambah. Selama variabel C2 kurang dari 61 detik, maka akan menapilkan output "detik detak" "ke:" variabel C2 variabel $\mathrm{C} 1$ pada layar LCD. Ketika variabel C2 sama dengan 60 detik, maka variabel $\mathrm{C} 1$ sebagai hasil pengukuran laju detak jantung selama 60 detik akan dikalikan dengan 1 yang kemudian hasilnya akan dimasukan ke dalam variabel detak. Selama variabel C2 lebih dari sama dengan 61 detik, maka akan menapilkan output "detak:" variabel detak "bpm" pada layar LCD. Ketika variabel $\mathrm{C} 2$ sama dengan 0 detik, maka variabel $\mathrm{C} 1$ akan direset dan pengukuran laju detak jantung akan terus berulang. Program akan selesai ketika tombol power ditekan.

\section{Cara Kerja Alat Pengukur Laju Detak Jantung}

Alat pengukur laju detak jantung menggunakan teknologi optik sebagai sensor 
untuk mendeteksi aliran darah di dalam kulit pada arteri radial ujung jari. Teknologi optik yang digunakan pada perancangan alat ini yaitu LED inframerah dan fotodioda. LED inframerah dan fotodioda ditempatkan pada bidang yang sama sedangkan ujung jari ditempatkan diatas LED inframerah dan fotodioda. LED inframerah berfungsi sebagai pemancar cahaya, fotodioda berfungsi sebagai penerima cahaya, sedangkan ujung jari berfungsi sebagai reflektor yang akan merefleksikan pancaran cahaya yang dipancarkan oleh LED inframerah. Terdapat tiga fase yang digunakan untuk mendeteksi sinyal detak jantung pada ujung jari yaitu deteksi pulsa, ekstraksi sinyal, dan amplifikasi pulsa. Sinyal detak jantung yang sudah terdeteksi oleh rangkaian sensor akan difiltrasi terlebih dahulu menggunakan Band Pass Filter (BPF), sehingga hanya frekuensi yang berada diantara $1,54 \mathrm{~Hz}$ sampai $2,34 \mathrm{~Hz}$ yang akan dilewatkan. Sinyal yang sudah difiltrasi tersebut akan dikuatkan oleh IC LM358 sebagai operational amplifier non inverting yang kemudian akan diproses oleh PLC mikro untuk ditampilkan hasil laju detak jantungnya pada layar LCD. Secara umum, cara kerja dari alat ini dapat dilihat pada Gambar 6.

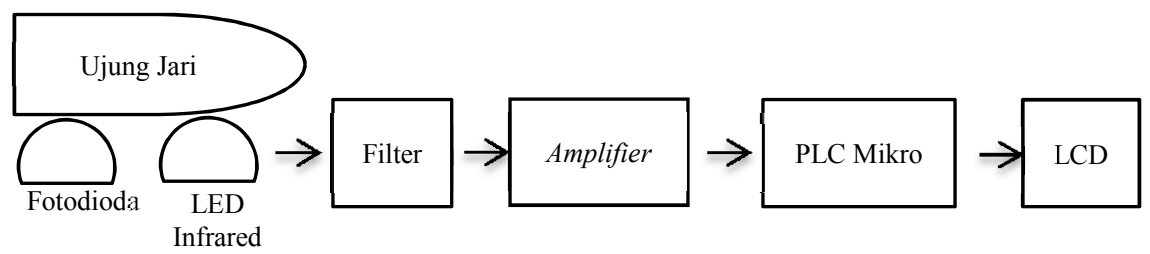

Gambar 6. Diagram blok pengukur laju detak jantung

\section{HASIL DAN PEMBAHASAN}

Kinerja dari alat pengukur laju detak jantung yang dibuat akan dikalibrasi dengan menggunakan alat medis yang bernama Automatic Blood Pressure Monitor dari Omron untuk membandingkan hasil pengukuran detak jantung seperti yang nampak pada Gambar 7. Alat Automatic Blood Pressure Monitor akan berfungsi sebagai actual heart rate, sedangkan alat pengukur laju detak jantung yang dibuat akan berfungsi sebagai measured heart rate.

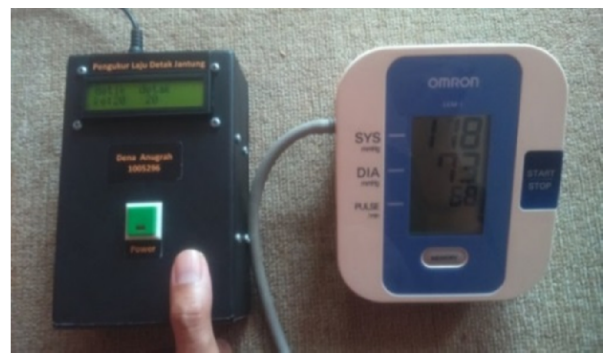

Gambar 7. Kalibrasi alat pengukur laju detak jantung dengan Automatic Blood Pressure Monitor dari Omron
Pengujian kedua alat ini akan dilakukan kepada 5 orang dengan lima kali pengukuran setiap orangnya untuk melihat tingkat keakuratan alat pengukur laju detak jantung yang dibuat. Hasil pengukuran laju detak jantung dari kedua alat ini dapat dilihat pada Tabel 1. Tingkat akurasi dari hasil pengukuran laju detak jantung dapat dilihat pada Gambar 8. Untuk menghitung tingkat kesalahan (error rate) dari alat pengukur laju detak jantung ini dapat dihitung dengan menggunakan rumus sebagai berikut:

$\mathrm{E}=\frac{([|\mathrm{RA}-\mathrm{RM}| \mathrm{x} 100])}{R A}$

Keterangan:

$\mathrm{E}=$ error rate $(\%)$

$\mathrm{RA}=$ rata-rata actual heart rate $(\mathrm{bpm})$

$\mathrm{RM}=$ rata-rata measured heart rate $(\mathrm{bpm})$ 
Tabel 1. Hasil pengukuran laju detak jantung

\begin{tabular}{|c|c|c|c|c|c|c|c|c|c|c|c|c|c|c|}
\hline \multirow[b]{2}{*}{$\begin{array}{l}\mathbf{N} \\
\mathbf{0}\end{array}$} & \multirow[b]{2}{*}{ Nama } & \multicolumn{5}{|c|}{ Actual Heart Rate (bpm) } & \multirow[b]{2}{*}{$\begin{array}{l}\text { Rata-Rata } \\
\text { Actual } \\
\text { Heart Rate } \\
\text { (bpm) }\end{array}$} & \multicolumn{5}{|c|}{ Measured Heart Rate (bpm) } & \multirow{2}{*}{$\begin{array}{c}\text { Rata- } \\
\text { Rata } \\
\text { Measured } \\
\text { Heart } \\
\text { Rate } \\
\text { (bpm) } \\
\end{array}$} & \multirow[b]{2}{*}{$\begin{array}{c}\text { Erro } \\
\text { r } \\
\text { Rate } \\
(\%)\end{array}$} \\
\hline & & 1 & 2 & 3 & 4 & 5 & & 1 & 2 & 3 & 4 & 5 & & \\
\hline 1 & $\begin{array}{c}\text { Gugu } \\
\mathrm{n}\end{array}$ & 74 & 74 & 76 & 76 & 75 & 75 & 76 & 72 & 78 & 75 & 75 & 75 & 0 \\
\hline 2 & Diki & 93 & 90 & 91 & 90 & 91 & 91 & 92 & 90 & 91 & 91 & 90 & 91 & 0 \\
\hline 3 & $\begin{array}{c}\text { Ahma } \\
\text { d }\end{array}$ & 102 & 102 & 100 & 101 & 102 & 101 & 104 & $\begin{array}{c}10 \\
3\end{array}$ & $\begin{array}{c}10 \\
1\end{array}$ & $\begin{array}{c}10 \\
1\end{array}$ & $\begin{array}{c}10 \\
0\end{array}$ & 102 & 0,99 \\
\hline 4 & Usup & 81 & 73 & 75 & 75 & 73 & 75 & 83 & 73 & 73 & 73 & 74 & 75 & 0 \\
\hline 5 & Udin & 72 & 70 & 70 & 70 & 72 & 71 & 70 & 73 & 73 & 70 & 70 & 71 & 0 \\
\hline & \multicolumn{13}{|c|}{ Rata-Rata Error Rate } & $\begin{array}{c}0,19 \\
8\end{array}$ \\
\hline
\end{tabular}

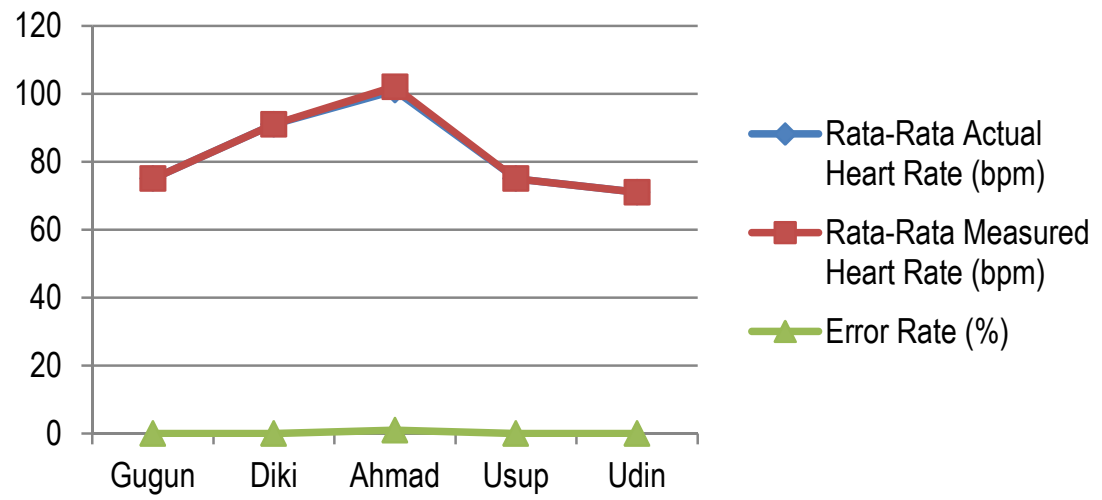

Gambar 8. Grafik hasil pengukuran laju detak jantung

Dalam proses kalibrasi, alat medis Automatic Blood Pressure Monitor dan alat pengukur laju detak jantung yang dibuat harus dilakukan secara bersamaan pada kondisi badan yang sama. Proses kalibrasi dilakukan pada kedua tangan, dimana setiap tangan akan diukur laju detak jantungnya menggunakan satu alat ukur. Alat medis Automatic Blood Pressure Monitor memiliki dua fungsi yang dapat bekerja secara otomatis dan bersamaan. Kedua fungsi ini yaitu untuk mengukur tekanan darah sebagai fungsi primer dan mengukur laju detak jantung sebagai fungsi sekunder. Sedangkan alat pengukur laju detak jantung yang dibuat hanya dapat digunakan untuk mengukur laju detak jantung saja. Pada alat medis Automatic Blood Pressure Monitor, hasil pengukuran tekanan darah dan laju detak jantung akan muncul pada LCD secara bersamaan. Sedangkan pada alat pengukuran laju detak jantung yang dibuat, hasil pengukurannya akan muncul setelah menunggu selama 60 detik. Alat pengukur laju detak jantung yang dibuat sengaja diprogram untuk menampilkan hasil pengukuran setiap 60 detik sekali dengan tujuan untuk meminimalisir terjadinya tingkat kesalahan (error rate) dan kehilangan informasi. Hasil penghitungan tersebut akan secara otomatis dikalikan dengan 1 untuk mendapatkan hasil beats per minute (bpm), sehingga penggunaan alat ini akan terasa lebih akurat dan spesifik. Pada alat yang dibuat, pengukuran laju detak jantung akan terus berulang dan akan berhenti ketika tombol power ditekan.

Pengukuran laju detak jantung Gugun, Diki, Usup, dan Udin dilakukan pada kondisi badan yang sedang rileks sehingga menghasilkan laju detak jantung yang normal. Sedangkan pengukuran laju detak jantung Ahmad dilakukan pada kondisi badan setelah beraktivitas sehingga menghasilkan laju detak jantung yang takikardia. Dari hasil pengukuran laju detak jantung baik yang normal maupun yang takikardia masih dapat terdeteksi oleh 
alat pengukur laju detak jantung yang dibuat. Namun, pada setiap kali pengukuran, hasilnya ada yang sama dan ada pula yang berbeda antara actual heart rate dengan measured heart rate. Hasil pengukuran yang berbeda memiliki selisih detak jantung antara 1 bpm sampai 3 bpm. Error dalam hasil pengukuran tersebut terjadi karena adanya gerakan pada ujung jari yang sedang dilakukan pengukuran terhadap sensor pada alat yang dibuat. Gerakan pada ujung jari akan berpengaruh terhadap perubahan intensitas cahaya yang akan terdeteksi oleh sensor, sedangkan sensor yang digunakan untuk mengukur laju detak jantung bersifat sensitif.

Untuk menghitung rata-rata actual heart rate dan rata-rata measured heart rate digunakan pembulatan satuan dari hasil lima kali pengukuran, sebab tidak ada detak jantung yang bernilai desimal. Hasil pengukuran laju detak jantung dengan menggunakan kedua alat tersebut menghasilkan tingkat kesalahan (error rate) sebesar $0,198 \%$. Nilai kesalahan yang masih bisa ditolerir dalam pengukuran yaitu sebesar $0,6745 \%$, sehingga alat pengukur laju detak jantung yang dibuat dapat digunakan untuk mengukur laju detak jantung.

\section{SIMPULAN}

Alat yang dirancang dapat digunakan untuk mengukur laju detak jantung dan mempunyai akurasi yang tepat sesuai dengan standar yang telah ditetapkan dalam sistem pengukuran.

\section{DAFTAR RUJUKAN}

Dogan Ibrahim, Kadri Buruncuk. Heart Rate Measurement From The Finger Using a Low-Cost Microcontroller. Turkey: Near East University, 2006.

Lauralee Sherwood. Fisiologi Manusia dari Sel ke Sistem Edisi 2. Jakarta: EGC, 2001.

Dian Artanto. 60 Aplikasi PLC-Mikro. Jakarta: PT. Elex Media Komputindo, 2012.

Sharief F Babiker, Liena Elrayah Abdel-Khair, Samah M. Elbasheer. Microcontroller Based Heart Rate Monitor using
Fingertip Sensors. Sudan: University of Khartoum Engineering Journal. Vol 1, Issue 2, (October 2011): 47-51.

M.M.A. Hashem, Rushdi Shams, Md. Abdul Kader, Md. Abu Sayed. Design and Development of a Heart Rate Measuring Device using Fingertip. Bangladesh: Khulna University of Engineering \& Technology, 2010.

William D Cooper. Instrumentasi Elektronik dan Teknik Pengukuran Edisi ke 2. Jakarta: Erlangga, 1994. 